\title{
Penguatan Ketrampilan Legislasi bagi Mahasiswa Ilmu Pemerintahan, FISIP, Universitas Muhammadiyah Ponorogo
}

\author{
Yusuf Adam Hilman', Ekapti Wahjuni DJ², Robby Darwis Nasution ${ }^{3}$ \\ ${ }^{123}$ Program Studi Ilmu Pemerintahan, Fakultas Ilmu Sosial dan Ilmu Politik \\ Universitas Muhammadiyah Ponorogo \\ adam_hilman@umpo.ac.id, ekaptiwahyuni@gmail.com, darwisnasution69@gmail.com
}

\begin{abstract}
ABSTRAK
Pengabdian ini, bertujuan untuk memperkuat ketrampilan legislasi bagi mahasiswa Ilmu Pemerintahan, mitra pengabdian ini adalah Program Studi Ilmu Pemerintahan dan juga Dewan Perwakilan Daerah (DPRD) Kabupaten Ponorogo, Program Studi Ilmu Pemerintahan mengalami problematika ketika lulusan merasa kesulitan jika dalam bekerja berurusan dengan produk hukum. Tahapan pengabdian terdiri dari: 1). Tahap Orientasi. 2).Melakukan Focus Grub Discussion (FGD), 3). Kunjungan ke kantor DPRD Kabupaten Ponorogo. 4). Melakukan workshop dan seminar terkait penguatan ketrampilan praktik legislasi dengan mengundang mitra dan juga ahli dari DPRD Kabupaten Ponorogo. 5). Melakukan evaluasi terhadap pemahaman mahasiswa program studi ilmu pemerintahan melalui pembuatan buku, terkait teknik dan penyusunan perundang - undangan. Hasil pengabdian memperlihatkan penguatan ketrampilan mahasiswa program studi ilmu pemerintahan dalam memahami praktik legislasi di tempat kerja.

Kata kunci : Ketrampilan Legislasi, Mahasiswa, Pengabdian
\end{abstract}

\section{ABSTRACT}

This devotion aims to strengthen legislation skills of students government science, this is the program partner devotion, study the science of government and also local parliament Ponorogo District (DPRD), The program had problems it when government science graduates had difficulty if in work dealing with legal products. Phases of devotion consisting of 1). The stage orientation. 2). Do focus grub discussions (FGD). 3). Visiting the office of parliament Ponorogo District (DPRD). 4). Do workshop and a seminar related skills strengthening legislation practices by inviting partners and also experts from parliament Ponorogo District (DPRD). 5). Evaluating students understanding of a program of study the science of government through the provision of a book, related technique and the formulation of The Bill invitation. The shows devotion strengthening skills students study program in understanding the science of government legislation. practices at work.

Keywords: that legislation, students, devotion. 


\section{PENDAHULUAN}

Streotipe tentang kemiskinan hanya bisa dilawan dengan pendidikan, hingga saat ini masih saja menjadi perdebatan, jika ukuran sebuah keberhasilan atau kesuksesan adalah harta atau uang, maka kemiskinan tidak perlu dilawan dengan kesempatan memperoleh pendidikan, cukup dengan bekerja keras, berusaha, dan berdoa, maka akan menghasilkan pundi - pundi uang, akan tetapi perlu diingat bahwa karakteristik dari kemiskinan itu tidak sama dan berbeda - beda.

Sosiologis memiliki perspektif dalam melihat kemiskinan, dimana kemiskinan bisa dilihat dari cara pengukurannya, ada kemiskinan yang dilihat secara kuantitatif dan juga secara kualitatif, jika dilihat secara kuantitatif maka kemiskinan itu berkaitan dnegan kemampuan personal atau individual untuk memenuhi kebutuhan primer dan juga sekundernya, seperti pangan, pekerjaan, pendidikan dan lains ebagainya, sedangkan secara kualitatif kemiskinan dilihat dan diukur secara tekstual, hal tersebut mencakup tentang penggambaran atau deskripsi kemiskinan melalui narasi, melalui teks - teks, kontek yang kemudian divisualisasikan melalui video ataupun foto (Siahaan, 2011)

Ekonom atau ahli ekonomi menyebutkan jika kemiskinan memiliki kategorisasi, diantaranya: 1). kemiskinan absolut, 2).Kemiskinan relatif. Kategori yang pertama dapat di maknai sebagai sebuah kondisi masyarakat tidak mampu untuk memenuhi kebutuhan kebutuhan pokoknya, seperti sandang, pangan, kesehatan dan pendidikan. Sedangkan kemiskinan relatif lebih disebabkan oleh faktor - faktor internal atau pribadi dari setiap individu masyarakat (Iskandar, 2017).

Ketidakmampuan memenuhi kebutuhan pokok seperti pendidikan adalah sebuah ironi, karena dalam amanat undang - undang no 20 Tahun 2003 tentang sistem pendidikan nasional, sudah dijelaskan jika konstitusi menjamin semua warga Negara nya untuk bisa mendapatkan pendidikan sepanjang hayat. Amanat konstitusi harus benar - benar terwujud dan setiap warga Negara tuntas dalam mendapatkan pendidikan.

Sebagai sebuah sistem, pendidikan memiliki fungsi dan tujuan, dimana pendidikan berfungsi sebagai pengembangan kemampuan supaya terbentuk watak serta peradaban bangsa, 
sehingga semua masyarakat dapat menjadi insan yang cerdas, sedangkan tujuan pendidikan mengharapkan semua warga Negara yang menjadi peserta didik dapat menjadi manusia yang unggul, beriman, serta bertaqwakepada Tuhan Yang Maha Esa, berilmu, sehat, cakap, kreatif, mempunyai kemandirian sebagai warga Negara.

Proses pendidikan tersebut kemudian tereduksi pada lembaga - lembaga pendidikan, baik yang bersifat formal dan non formal, melalui lembaga tersebut kemudian aktifitas belajar mengajar dilakukan dengan mekanisme dan prosedur yang terukur, sehingga dalam pencapaian tujuan pendidikan bisa di kontrol dan terarah. Kelembagaan pendidikan secara sederhana dilakukan oleh lembaga pendidikan, dengan model berjenjang, mulai tingkat dasar yang disebut sekolah dasar (SD), tingkat menengah yang disebut (SMP/SLTP), kemudian tingkat Menengah atas (SMA, SLTA, SMK, STM) hingga tingkat perguruan tinggi atau disebut Universitas.

Tingkatan dasar hingga perguruan tinggi harus dilalui tahap demi tahap, sampai dinyatakan lulus dan memenuhi kompetensi yang diharapkan, khusus lembaga pendidikan di level perguruan tinggi, terdapat mekanisme pemilihan bidang sesuai dengan peminatan, ada beberapa bidang yang terdapat di level ini, yakni, bidang: sosial humaniora, eksakta, sain dan pendidikan, nantinya para pembelajar yang sudah lulus atau pada level perguruan tinggi bisa menjadi lulusan yang bisa langsung bekerja dan diterima oleh pengguna atau user. Ketika mahasiswa yang lulus mudah diterima oleh para pengguna, maka dia akan mendapatkan uang dari bekerja dan jenjang karir, sehingga dengan mudah dia akan mendapatkan kesempatan untuk memperbaiki kondisi dan menjauh dari kemiskinan.

Penerimaan terhadap lulusan oleh pengguna lulusan atau user akan memberikan gambaran terkait akuntabilitas sebuah lembaga pendidikan, hal ini penting untuk dipikirkan karena perguruan tinggi harus memikirkan sejauhmana alumni yang dihasilkan memiliki kompetensi dan juga kecakapan yang benar - benar dibutuhkan oleh pasar sehingga eksistensi (program studi/jurusan/fakultas) benar - benar dibutuhkan atau tidak (Setyaningsih, 2013).

Program Studi Ilmu Pemerintahan adalah salah satu level pendidikan di tingkat perguruan tinggi, yang memiliki Visi - Misi serta Tujuan untuk menghasilkan lulusan sarjana ilmu pemerintahan yang trampil, professional, mandiri dan berjiwa Islami sehingga memiliki 
keunggulan kompetitif baik di tingkat internasional dan nasional. Saat ini Program Studi Ilmu Pemerintahan FISIP, Universitas Muhammadiyah Ponorogo sudah terakreditasi "B" yang akan habis pada tahun 2020 .

Proses pembelajaran yang dilakukan di Program Studi Ilmu Pemerintahan walaupun sudah sesuai dengan mekanisme lembaga pendidikan di level perguruan tinggi, yang sistematis dan terukur, tetapi kadang kala masih memiliki kekurangan, salah satu fakta yang terungkap ketika kami melakukan beberapa wawancara dengan alumni yang menyebutkan jika, merasa tidak cakap atau kurang menguasai ketrampilan dalam bidang legislasi.

Penuturan alumni program studi ilmu pemerintahan, yang bekerja di instansi pemerintah menyebutkan jika, mereka merasa kesulitan jika behadapan dengan aturan, kebijakan, maupun undang - undang, karena tidak memiliki bekal yang cukup serta minimnya ketrampilan dalam praktik legislasi, yang berdampak pada kualitas pekerjaan yang mereka selesaikan. (Alumni IP FISIP UMPO, 2008)

Penelusuran dalam proses pembelajaran di program studi ilmu pemerintahan memberikan gambaran bahwa sebenarnya mahasiswa sudah mendapatkan mata kuliah pengantar ilmu hukum, sistem hukum Indonesia, dan juga teknik dan proses perundang - undangan, kenapa kemampuan mahasiswa lulusan ilmu pemerintahan masih sangat minim, hal inilah yang kemudian mendasari peneliti ingin memperkuat ketrampilan mahasiswa sebelum lulus dan memasuki dunia kerja .

Kebutuhan akan ketrampilan legislasi bagi mahasiswa ilmu pemerintahan, dirasakan pelu diupayakan, walaupun selama ini sudah ada atau terintegrasi dalam beberapa mata kuliah, nyatanya belum optimal, sehingga penting menurut kami untuk pengembangan soft skill bagi mahasiswa Ilmu Pemerintahan, dimana lulusan sarjana ilmu pemerintahan saat ini masih banyak yang belum paham atau sangat kesulitan jika berhubungan dengan pekerjaan yang menyangkut dengan undang - undang ataupun kebijakan, sehingga sangat disayangkan ketika lulusan prodi ilmu pemerintahan tidak cukup bekal ketika sudah lulus, padahal hal tersebut bisa dioptimalkan ketika masih menjadi mahasiswa. Keterbatasan program studi ilmu pemerintah menjadikan ketrampilan legislasi bisa di laksanakan di luar perkuliahan, supaya bisa lebih maksimal hasilnya. 
Menghadapi persoalan tersebut, maka diperlukan sebuah solusi yang konkrit terkait, upaya untuk menguatkan ketrampilan legislasi bagi mahasiswa Program Studi Ilmu Pemerintahan. Solusi yang kami tawarkan ada membuat sebuah model kegiatan yang dilakukan secara terstruktur, sehingga dapat di ukur capaian yang diharapkan yakni tingkat pemahaman dan ketrampilan teknis dalam hal pembuatan dan penyusunan perundang - undangan (Hidayat, 2017).

Model penguatan ketrampilan legislasi bagi mashasiswa program studi ilmu pemerintahan, meliputi beberapa tahapan, yakni:

1. Tahap Orientasi, yakni dengan melakukan penggalian sejauhmana mahasiswa program studi ilmu pemerintahan memiliki pemahaman dan ketrampilan teknis terkait penyusunan perundang - undangan.

2. Melakukan Focus Grub Discussion (FGD) untuk berdiskusi dan menemukan serta menguraikan poin - poin penting terkait kelemahan mahasiswa program studi ilmu pemerintahan dalam praktik legislasi.

3. Kunjungan ke kantor DPRD Kabupaten Ponorogo.

4. Melakukan workshop dan seminar terkait penguatan ketrampilan praktik legislasi dengan mengundang mitra dan juga ahli dari DPRD Kabupaten Ponorogo.

5. Melakukan evaluasi terhadap pemahaman mahasiswa program studi ilmu pemerintahan melalui pembuatan buku, terkait teknik dan penyusunan perundang - undangan.

Proses yang dilalui dan dilakukan secara bertahap, merupakan bentuk kegiatan pengabdian, dalam rangka pemahaman dan penguatan ketrampilan penyusunan perundang undangan, sehingga rangkaian kegiatan dari tahap satu hingga tahap selanjutnya adalah saling terkait dan berkesinambungan, sehingga bisa diukur dan terpenuhi tujuan dari praktik pengabdian.

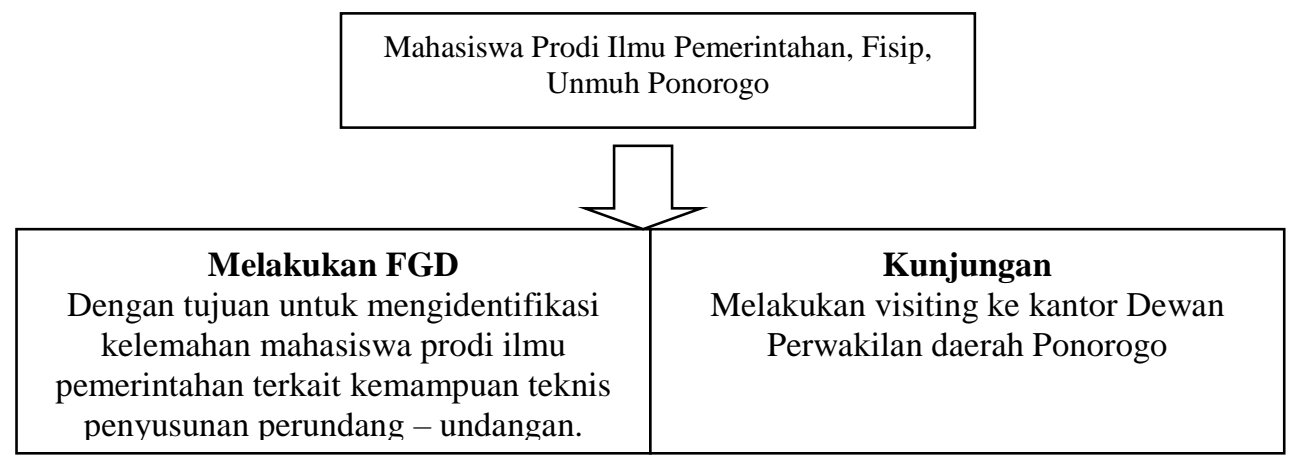




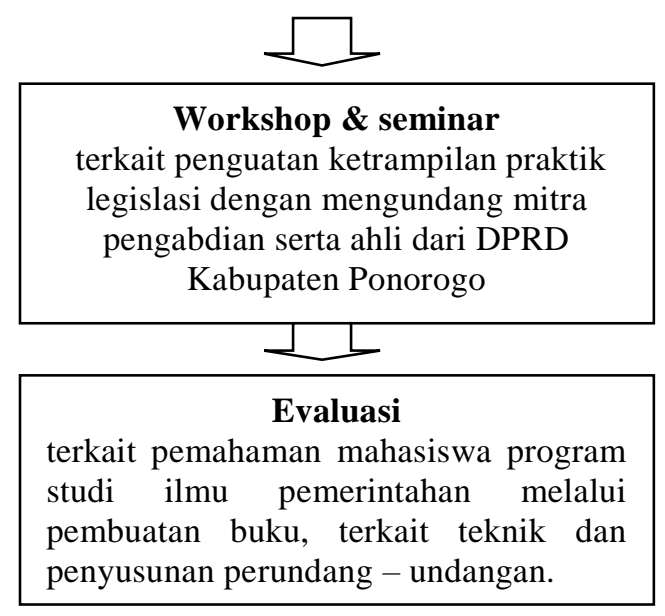

Gambar 1 Model Pengabdian masyarakat penguatan ketrampilan legislasi bagi mahasiswa program studi ilmu pemerintahan FISIP, Universitas Muhammadiyah Ponorogo

\section{METODE} Sumber: diolah dari data hasil penelitian

Solusi yang dilakukan untuk mengatasi kelemahan mahasiswa program studi ilmu pemerintahan, dalam hal pemahaman serta teknis penyusunan undang - undang dilakukan melalui beberapa tahapan, diantaranya adalah:

\section{1) Kegiatan Focus Grub Discussion (FGD)}

Kegiatan FGD yang dilakukan bertujuan untuk mengetahui apa saja yang menjadi kelemahan - kelemahan yang di miliki mahasiswa ilmu pemerintahan, FISIP, Universitas Muhammadiyah Ponorogo, terkait dengan pemahan dan ketrampilan dalam praktik legislasi, kegiatan ini dilakukan pada tanggal 10 November 2018, melibatkan dosen - dosen di program studi ilmu pemerintah, dan beberapa pakar di bidang legislasi. 


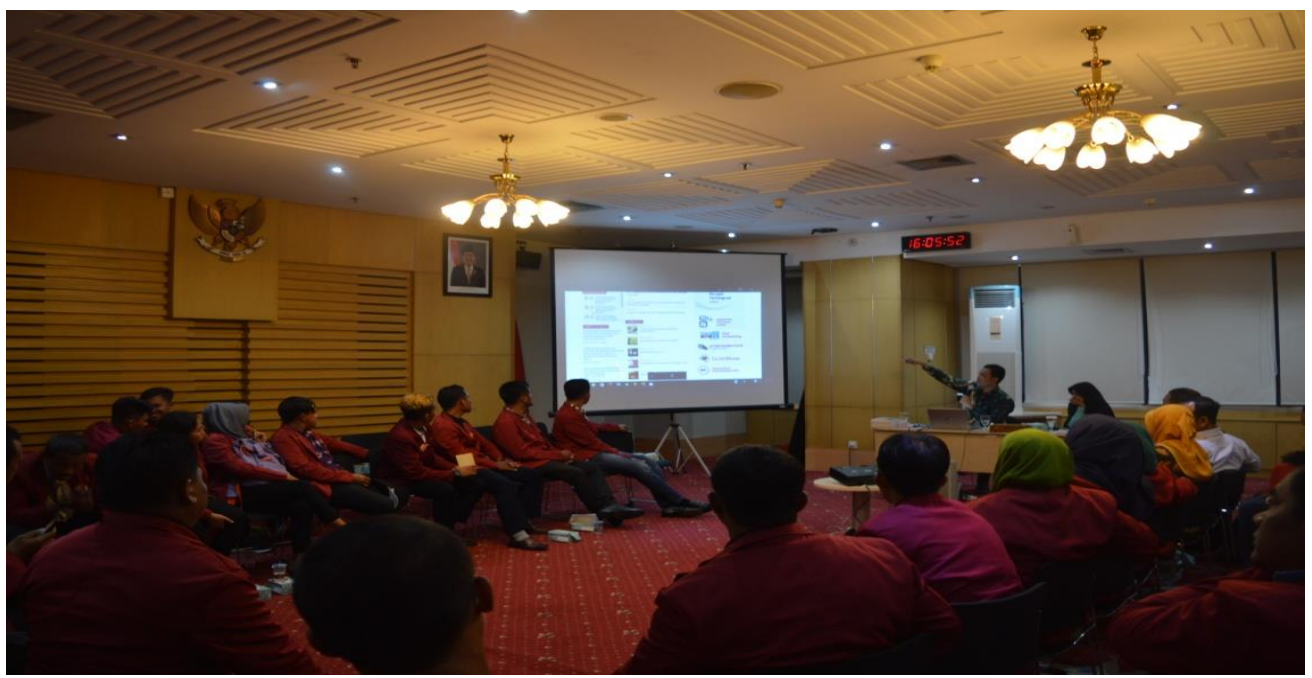

Gambar 2 Focus Grub Discussion Mahasiswa Prodi Ilmu Pemerintahan Sumber: diolah dari dokumentasi hasil pengabdian

2) Kunjungan di kantor DPRD kabupaten Ponorogo

Kegiatan kunjungan ke kantor Dewan Perwakilan Daerah (DPRD) Kabupaten Ponorogo, bertujuan untuk mengetahui bagaimana struktur organisasi dan kesekertariatan yang ada di lembaga legislatif tersebut, sehingga mahasiswa ilmu pemerintahan mengetahui seluk - beluk tugas pokok dan fungsi dari lembaga ini. kegiatan tersebut dilakukan pada 28 November 2018. Tahapan ini merupakan rangkaian proses pengabdian yang sudah di jadwalkan secara terstruktur.

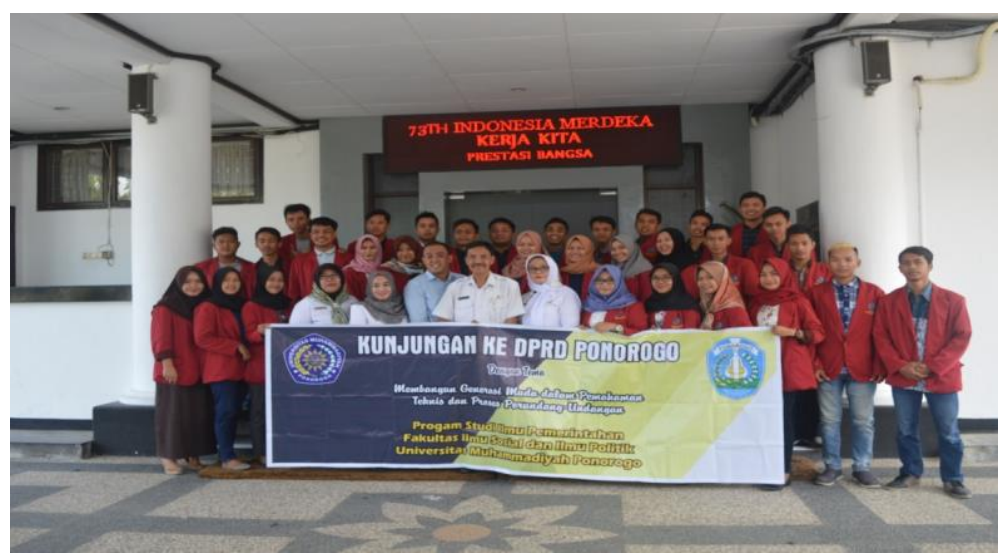


Gambar 3 Kunjungan Mahasiswa Prodi Ilmu Pemerintahan ke DPRD Kabupaten Ponorogo Sumber: diolah dari dokumentasi hasil pengabdian

3) Melakukan kegiatan Workshop \& seminar

Kegiatan Workshop dan seminar merupakan salah satu tahapan dalam kegiatan pengabdian yang dilakukan kelompok kami, acara ini diselenggarakan di universitas muhammadiyah ponorogo dengan sasaran peserta yakni mahasiswa program studi ilmu pemerintahan, FISIP, dalam acara tersebut tampil sebagai materi adalah bapak Drs. Subakir, M.M (Kabag Hukum dan Perundang-Undangan DPRD Kabupaten Ponorogo), tujuan kegiatan ini adalah memberikan pemahaman dan juga ketrampilan teknis dalam praktik legislasi. Kegiatan ini terselenggara pada tanggal 21 Januari 2019 bertempat di ruang seminar Dome Universitas Muhammadiyah Ponorogo.

Pada kesempatan tersebut pemateri menyampaikan jika dalam dunia kerja khususnya di lembaga legislatif sangat dibutuhkan kemampuan teknis dan pemahaman yang baik terkait proses penyusunan rancangan undang - undang guna meminimalisir produk hukum yang akan dibuat, selain itu jika anggota dewan memiliki pemahaman yang baik maka produk hukum yang dihasilkan akan memiliki kualitas yang baik, sehingga kegiatan seperti ini sangat diperlukan bagi mahasiswa program studi ilmu pemerintahan yang memang nantinya sangat dibutuhkan di dunia pemerintahan, baik bekerja sebagai birokrat ataupun politisi.

Beberapa peserta menyatakan jika kegiatan seperti ini sangat penting untuk menambah wawasan yang dapat dijadikan sebagai bekal nantinya didunia kerja, khususnya di lembaga pemerintahan, yang dalam kesehariannya berkutat dengan produk - produk hukum, mengingat hal tersebut merupakan instrumen penting dalam proses pembuatan kebijakan. 


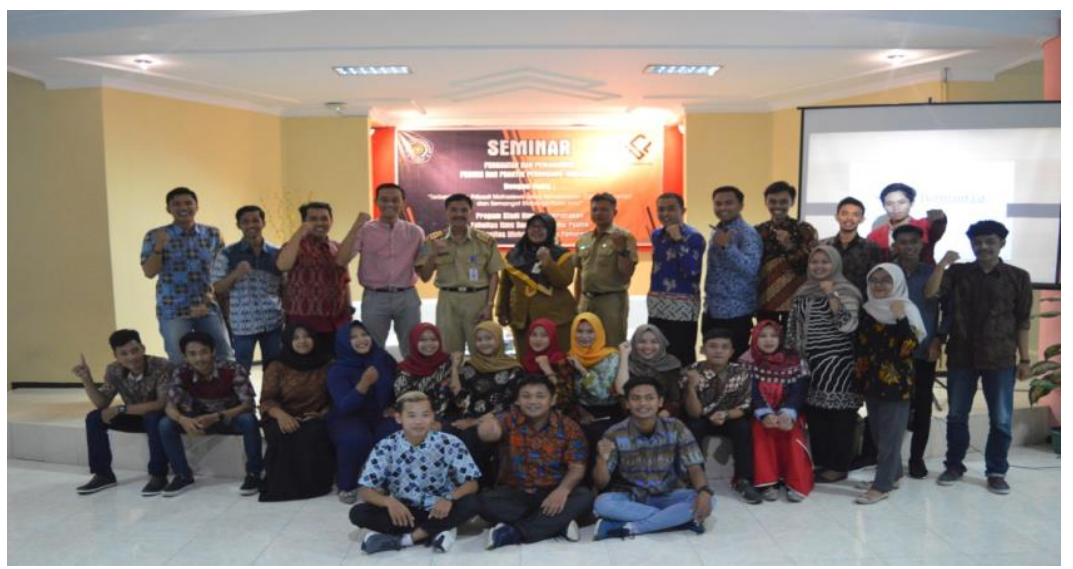

Gambar 4 Workshop dan Seminar Proses dan Teknis penyusunan Praturan Perundang - undangan Sumber: diolah dari dokumentasi hasil pengabdian

Kegiatan tersebut juga di publikasikan melalui media Koran yang terbit pada diharian ponorogo pos, yang terbit di hari jum'at bulan februari 2019.

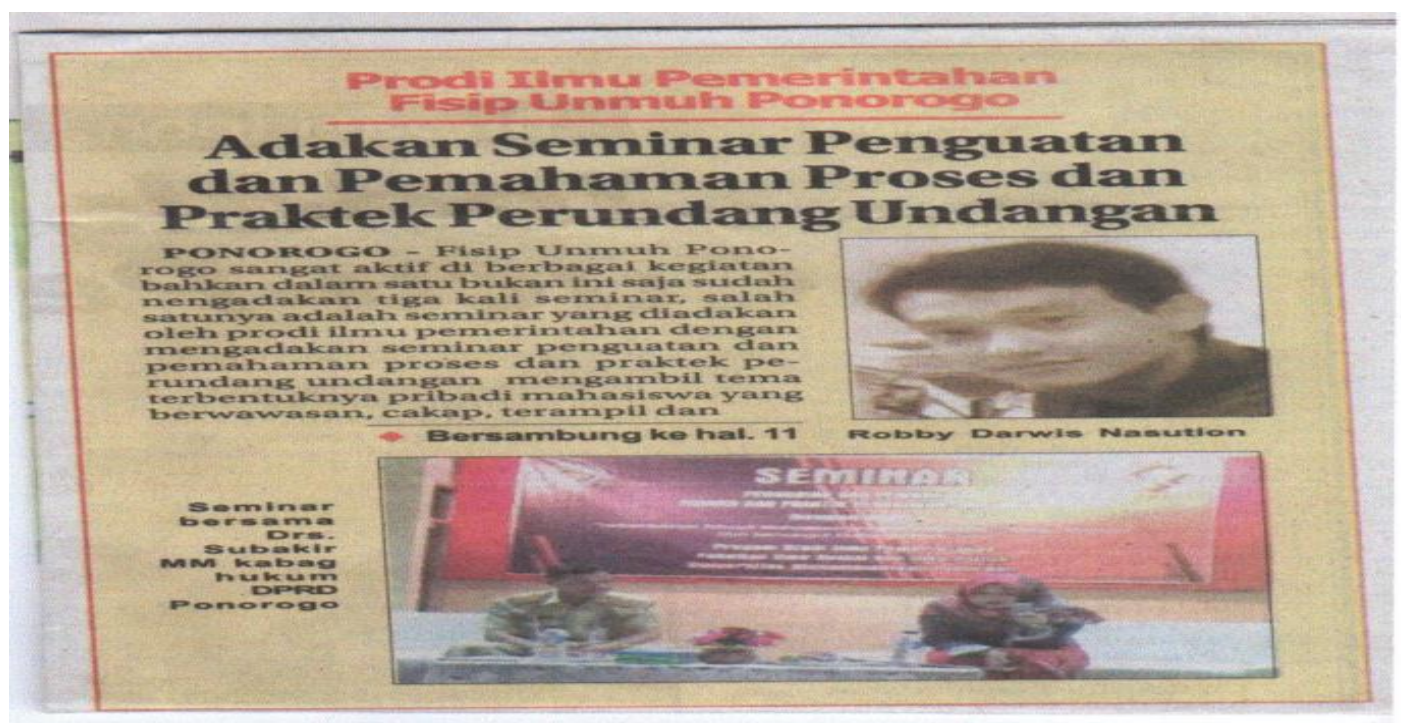

Gambar 5 Publikasi media cetak terkait kegiatan Seminar penguatan dan pemahaman Proses dan praktik Praturan Perundang - undangan

Sumber: diolah dari dokumentasi hasil pengabdian

4) Evaluasi terhadap pemahaman dan ketrampilan teknis penyusunan undang - undang

Tahapan pengabdian selanjutnya yaitu dengan melakukan evaluasi, dimana model evaluasi yang digunakan adalah dengan membuat buku, mahasiswa program studi ilmu 
pemerintahan diberikan tugas secara berkelompok untuk membuat sebuah draff buku, sebelum melakukan penyusunan draff buku, mahasiswa terlebih dahulu dibagi kedalam beberapa kelompok, dengan tema - tema yang telah ditentukan, kemudian dilakukan bimbingan secara intensif untuk subtansi artikel hingga selesai, kemudian buku di daftar ISBN, dan proses pencetakan.

Saat ini proses penyusunan buku sudah pada tahap pencetakan, dimana buku tersebut berjudul "praktik dalam memahami teknik dan proses penyusunan perundangan - undangan di Indonesia" dengan nomor ISBN : 978 -602-0791-30-2.

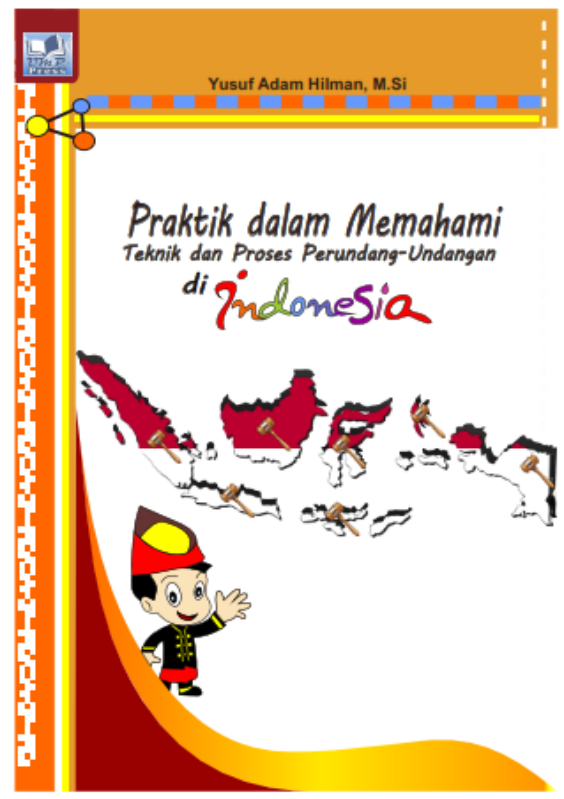

Gambar 6 Publikasi Buku berjudul praktik dalam memahami praktik dan Proses Praturan Perundang undangan

Sumber: diolah dari dokumentasi hasil pengabdian

\section{HASIL DAN PEMBAHASAN}

Program studi Ilmu Pemerintahan, Fakultas Ilmu Sosial dan Ilmu Politik, Universitas Muhammadiyah Ponorogo, merupakan salah satu program studi yang memiliki capaian lulusan sebagai birokrat, politisi dan perangkat desa yang professional, untuk mencapai hal tersebut maka lulusan sudah sejak dini perlu dipersiapkan soft skill serta 
kemampuan teknis penunjang yang akan dibutuhkan dalam dunia kerja. Ketrampilan dalam hal pemahaman dan teknis penyusunan perundang - undang merupakan salah satu kebutuhan lulusan, oleh karena itu kami mencoba membuat sebuah model penguatan ketrampilan legislasi bagi mahasiswa prodi ilmu pemerintahan, adapun tahapan pengabdian yang kami lakukan, meliputi beberapa tahapan yakni, sebagai berikut:

\section{a) Tahap Orientasi}

Tahapan ini merupakan proses awal identifikasi seputar permasalahan terkait pengetahuan mahasiswa program studi ilmu pemerintahan, FISIP, Universitas Muhammadiyah Ponorogo, berkenaan dengan ketrampilan teknis dan proses penyusunan perundang - undangan, dimana banyak alumni yang menyatakan jika mereka mengalami kesulitan jika dalam pekerjaan berurusan dengan produk hukum, seperti peraturan desa (perdes), peraturan desa (perda) dan lain - lain.

Saya merasa tidak percaya diri jika dalam pekerjaan bertemu atau berurusan dengan kebijakan atau produk hukum, mungkin karena saya tidak cukup memiliki pemahaman tentang praktik dan proses perundang - undangan. (Yudiono alumni Ilmu Pemerintahan Tahun 2018)

Ketika pimpinan mendelegasikan tugas untuk memahami sebuah produk hukum, saya merasa kesulitan, selain saya merasa tidak begitu paham, saya juga mengalami kebingungan, sehingga menurut saya lulusan program studi ilmu pemerintahan harus memiliki ketrampilan yang cukup terkait teknik dan proses penyusunan perundang undangan. (Tegar Aji Saputra alumni Ilmu Pemerintahan Tahun 2018)

Dalam pekerjaan saya selalu berkutat dengan aturan dan produk hukum, saya merasa minder, karena tidak memiliki pemahaman yang cukup terkait penyusunan peraturan perundang - undangan, harapan saya setiap lulusan ilmu pemerintahan bisa menguasai kopetensi tersebut. (Siti Azizah alumni Ilmu Pemerintahan Tahun 2018)

Penuturan beberapa alumni, menyebutkan bahwa ketrampilan dalam memahami proses penyusunan perundang - undangan sangat penting dalam dunia kerja, sehingga diperlukan soft skill tambahan untuk menunjang kempetensi dalam dunia kerja, tidak hanya yang masuk atau include dalam mata kuliah teknik dan proses perundang - undang. 


\section{b) Melakukan Focus Grub Discussion (FGD)}

Kegiatan Focus Grub Discussion (FGD) dilakukan dengan melibatkan mahasiswa serta dosen, tujuannya adalah untuk mengetahui hal - hal apa saja yang belum dipahami oleh mahasiswa terkait dengan teknik dan proses penyusunan undang - undang, disni akan terjadi diskusi serta pertukaran pendapat, sehingga dapat diperoleh poin - poin penting tersebut, diantaranya: i). Mahasiswa belum paham apa yang dimaksud dengan peraturan perundang - undangan, ii). Mahasiswa belum bisa membedakan jenis - jenis produk hukum, dan level tingkatan dari yang tertinggi hingga yang terendah, iii). Mahasiswa belum memahami azas - azas dalam pengundangan, iv). Mahasiswa belum memahami lembaga Negara yang bertugas membuat peraturan perundang - undangan, v). Mahasiswa belum memahami alur penyusunan peraturan perundang - undangan.

Dalam kegiatan ini, mahasiswa ilmu pemerintahan sangat aktif berperan, ketika diminta berpendapat mereka secara partisipatif dan mengutarakan pendapat nya, hingga kegiatan FGD berjalan secara dinamis.

\section{c) Kunjungan ke kantor DPRD Kabupaten Ponorogo}

Kunjungan ke kantor kesekertariatan Dewan Perwakilan Daerah (DPRD) Kabupaten Ponorogo bertujuan untuk mengetahui bagaimana struktur organisasi lembaga ini, selain itu diharapkan dengan kunjungan tersebut mahasiswa ilmu pemerintahan bisa memahami pelaksanaan tugas pokok dan fungsi lembaga ini. Dari hasil kunjungan ke kesekertariatan Dewan Perwakilan Daerah (DPRD), kami mendapatkan banyak penjelasan terkait apa saja fungsi dan juga tugas dari lembaga ini, sehingga kita mengetahui secara detail, apa saja sebenarnya yang dilakukan oleh lembaga ini. pada kunjungan tersebut mahasiswa secara aktif bertanya kepada pihak Kesekertariatan sehingga kunjungan tersebut sangat kondusif, nampak mahasiswa ilmu pemerintahan menikmati perbincangan hingga acara selesai. 
Tabel 1 Tugas dan Fungsi DPRD

\begin{tabular}{|c|c|}
\hline Tugas DPRD & Fungsi DPRD \\
\hline Membentuk peraturan daerah & Fungsi legislasi \\
\hline $\begin{array}{l}\text { Tugas yang paling dominan dilakukan adalah, } \\
\text { menginisiasi pembentukan peraturan daerah yang } \\
\text { akan dibahas dengan lembaga eksekutif di level } \\
\text { Provinsi, Kota / kabupaten, sehingga tercipta } \\
\text { produk hukum yang berkualitas dan berimbang. }\end{array}$ & $\begin{array}{l}\text { Secara sederhana fungsi ini melekat pada } \\
\text { pelaksanaan tugas nya sebagai pembuatan peraturan } \\
\text { daerah. }\end{array}$ \\
\hline $\begin{array}{l}\text { Memberi persetujuan pemindah tanganan asset } \\
\text { daerah. }\end{array}$ & fungsi anggaran \\
\hline $\begin{array}{l}\text { Terkait tugas ini, maka DPRD Bertugas untuk } \\
\text { melakukan persetujuan terhadap pemindahan dan } \\
\text { kepemilikan aset daerah. }\end{array}$ & $\begin{array}{l}\text { secara sederhana fungsi ini menjelaskan bagaimana } \\
\text { dewan perwakilan daerah ikut serta dalam } \\
\text { pembahasan dan persetujuan dalam penyusunan } \\
\text { anggaran. }\end{array}$ \\
\hline Melaksanakan pengoperasian dan penyerapan & Fungsi pengawasan \\
\hline $\begin{array}{l}\text { anggaran daerah } \\
\text { Selain menjalankan tugas untuk menyetujui dan } \\
\text { tidak menyetujui anggaran, DPRD juga memiliki } \\
\text { tugas mengontrol penyerapan operasinal anggaran } \\
\text { di daerah. }\end{array}$ & $\begin{array}{l}\text { Dewan Perwakilan Daerah berfungsi untuk } \\
\text { mengawasi dan mengontrol penyelenggaraan } \\
\text { pemerintah di level daerah }\end{array}$ \\
\hline $\begin{array}{c}\text { Menyerap, menghimpun dan menindaklanjuti } \\
\text { aspirasi masyarakat }\end{array}$ & \\
\hline $\begin{array}{l}\text { Selain melakukan tugasnya untuk membuat aturan } \\
\text { atau regulasi, disini DPRD juga menjadi wadah } \\
\text { aspirasi masyarakat, seringkali tugas penyusunan } \\
\text { undang - undang lahir dari aspirasi masyarakat. }\end{array}$ & \\
\hline
\end{tabular}

Sumber: diolah dari hasil penelitian 


\section{d) Melakukan workshop dan seminar}

Kegiatan seminar dan workshop teknik dan proses penyusunan peraturan perundang undangan adalah kegiatan yang melibatkan mahasiswa dosen dan praktisi, dalam kegiatan ini tampil sebagai pemateri yakni bapak Drs. Subakir, M.M (Kabag Hukum dan PerundangUndangan DPRD Kabupaten Ponorogo), tujuan kegiatan tersebut adalah memberikan pemahaman terkait teknik dan proses penyusunan peraturan perundang - undangan, dalam kegiatan tersebut, diperoleh gambaran dari mahasiswa yang kami wawancarai, beberapa hal penting yang menjadi poin dari tujuan penyelenggaraan acara tersebut.

Alhamdulilah, saya sebagai mahasiswa ilmu pemerintahan, yang mengikuti acara seminar tersebut, banyak mendapatkan ilmu dan juga pencerahan dari materi tersebut, sehingga bertambang pengetahuan serta pemahaman kami, terkait dnegan teknik dan proses perundang - undangan. (Supriyadi mahasiswa ilmu pemerintahan angkatan tahun 2017)

Saya banyak mendapatkan ilmu dari kegiatan seminar tersebut, selain menambah wawasan, juga secara teknis mendapatkan gambaran bagaimana proses penyusun peraturan perundang undangan. (Bilqis Farah mahasiswa Ilmu Pemerintahan angkatan 2017)

Kegiatan tersebut sangat bagus, karena secara sederhana saya dapat menangkap poin - poin yang disampaikan oleh pemateri sehingga saya menjadi paham terkait bagaimana seluk beluk dalam penyusunan produk hukum. (Arif Puja Mahasiswa Ilmu Pemerintahan angkatan 2017)

Mahasiswa mengikuti acara dari awal sampai akhir, mereka aktif bertanya dalam kegiatan seminar sehingga ada komunikasi yang kondusif secara dua arah, pesan menjadi lebih mudah di sampaikan antara pemateri dengan mahasiswa sebagai audience. Beberapa gambaran dari mahasiswa ilmu pemerintahan angkatan tahun 2017 menunjukan jika acara seminar tersebut berdampak positif terhadap pemahaman mereka yang semakin meningkat terkait proses penyusunan perundang - undangan.

\section{e) Melakukan evaluasi}

Setelah tahapan pengabdian selesai, kemudian pengabdi melakukan proses evaluasi yakni dengan membuat sebuah tugas penyusunan draf artikel buku terkait materi dan pemahaman 
materi teknik dan proses perundang - undang, dalam penyusunan tersebut mahasiswa ilmu pemerintahan di damping oleh dosen program studi untuk dibimbing dan diarahkan dalam penyusunan hingga selesai, setiap bab dalam buku tersebut juga di lakukan proses scan plagiasi, sehingga kualitas buku kolaborasi dosen dan mahasiswa ini menjadi lebih baik. saat ini buku sudah selesai menunggu proses pencetakan. Kenapa kami memilih media pembuatan buku untuk evaluasi kegiatan pengabdian ini, dikarenakan dengan buku mahasiswa bisa menuangkan buah pemikiran nya setelah dilakukan kegiatan ini, poin - poin yang mahasiswa pahami bisa disampaikan secara tertulis dan dapat dibaca oleh oleh orang lain, sehingga terjadi sharing knowledge.

\section{KESIMPULAN}

Pengabdian yang dilakukan oleh tim terkait penguatan pemahaman dan ketrampilan praktik legislasi bagi mahasiswa program studi ilmu pemerintahan, Fakultas Ilmu Sosial \& Ilmu Politik, Universitas Muhammadiyah Ponorogo, dilakukan secara bertahap, dengan proses sebagai berikut : 1). Tahap Orientasi, yakni penggalian informasi atau realitas terkait kebutuhan ketrampilan legislasi bagi lulusan ilmu pemerintahan, 2). Melakukan Focus Grub Discussion (FGD) dengan cara berdiskusi secara intensif dengan para akademisi untuk mengetahui hal - hal apa saja yang menjadi kelemahan mahasiswa dalam teknik dan proses penyusunan perundang - undangan, 3). Kunjungan ke kantor DPRD Kabupaten Ponorogo, kegiatan ini dilakukan dalam rangka memberikan gambaran kepada mahasiswa ilmu pemerintahan terkait proses pembuatan regulasi sebagai salah satu fungsi DPRD atau lembaga legislative, 4). Menyelenggarakan workshop praktik legislasi dengan mengundang mitra dan juga ahli dari DPRD Kabupaten Ponorogo, kegiatan ini diharapkan mampu memperkuat pemahaman dan juga teknis terkait seluk beluk terkait penyusunan undang - undang, 5). Tahap evaluasi dilakukan melalui pembuatan buku, dimana penyusunan draff buku adalah hasil dari pemahaman dan juga pengetahuan mahasiswa ilmu pemerintahan yang diperoleh dari setiap kegiatan atau tahapan dalam proses pengabdian.

Kegiatan pengabdian ini tentunya harus dilakukan secara berkelanjutan, untuk 
memaksimalkan tercapainya tujuan kegiatan tersebut, selain itu kegiatan ini harus melibatkan lebih banyak pihak, yang expert dalam bidang teknik dan proses perundang - undangan, supaya kualitas materi yang disampaikan menjadi lebih baik.

\section{UCAPAN TRIMAKASIH}

Ucapkan terimakasih yang pertama kami ucapkan kepada Program Studi Ilmu Pemeirntahan, FISIP, Universitas Muhammadiyah Ponorogo, kemudian Dewan Perwakilan Daerah (DPRD) Kabupaten Ponorogo atas kesediaanya menjadi mitra kami dalam membantu aktifitas pengabdian dari awal hingga akhir.

\section{DAFTAR PUSTAKA}

Hidayat, A. (2017). Budaya Kerja, Kepuasan Kerja Dan Kinerja Pegawai Pt. Trijaya Medika Farma: Motivasi Sebagai Moderator. Sains: Jurnal Manajemen Dan Bisnis, 10(1), 377-389. https://doi.org/10.35448/jmb.v10i1.4274

Iskandar, S. (2017). Karaktersitik dan akar permasalahan kemiskinan Kasus Pada 4 Tipologi Desa di Kabupaten Sumbawa. Jurnal Ekonomi Pembangunan: Kajian Masalah Ekonomi dan Pembangunan, 122 - 134.

Setyaningsih, I. \&. (2013). Tingkat Kepuasan Pengguna Lulusan berdasarkan tingkat kepuasan pengguna lulusan. Ilmiah Teknik Industri, 73-82.

Siahaan, H. (2011). Profil Kemiskinan di Surabaya: Sebuah Analisis Fenomenologis. Jurnal Kemiskinan, 219-227.

Undang - undang nomor 20 Tahun 2003 Tentang Sistem Pendidikan Nasional

Hasil wawancara dengan informan khususnya mahasiswa ilmu pemerintahan yang terlibat dalam kegiatan pengabdian ini. 